\title{
ІНІЦАЦІЯ ЯК ПОЕТИКАЛЬНА ОЗНАКА НОВЕЛ С. ЦВЕЙГА (НАУКОВО-МЕТОДИЧНІ МАТЕРІАЛИ ДО ВИВЧЕННЯ НОВЕЛІСТИЧНОЇ СПАДЩИНИ ПИСЬМЕННИКА У ВИШІ)
}

\author{
Олена Тереховська
}

\author{
Кандидат філологічних наук, доцент, \\ Кафедра світової літератури і порівняльного літературознавства, \\ Прикарпатський національний університет імені Василя Стефаника (УКРАЇНА), \\ 76018, м. Івано-Франківськ, вул. Шевченка, 57, \\ e-mail: olena.terekhovska@pu.if.ua
}

\section{РЕФЕРАТ}

У статті йдеться про поетикальну специфіку новел С. Цвейга, зокрема в аспекті їхньої структури. $\boldsymbol{M e m a}$ - довести, що ініціація $є$ поетикальною ознакою новел С. Цвейга, а також узагальнити й адаптувати науково-теоретичний матеріал з цієї проблеми для студентів-філологів під час їхньої підготовки до практичних і семінарських занять. Дослідницька методика полягає в екстраполяції поняття ініціації як специфічного соціально-психологічного феномену на художній текст новел С. Цвейга, а також у визначенні ініціації, що становить зміст і сутність кульмінаційного моменту в новелі, специфічною поетикальною ознакою цього жанру. Результати дослідження. Доведено, що кульмінаційний момент, закладений у саму природу новели на рівні іiі структури, утворюється за рахунок взаємодії двох специфічних особливостей новелістичного жанру - сюжету і підсюжету. 3'ясовано, що в сюжеті розгортаються події 3 життя героя, змальовуються зміни, до яких вони призвели в його почуттях чи свідомості; у підсюжеті паралельне розкриття сил, не усвідомлюваних героєм, які, проте, стали причиною саме такого розвитку подій і якісних змін внутрішнього світу героя - ініціації. Встановлено, що в кульмінаційний момент, коли схрещуються сюжетна і підсюжетна лінії, - народжується ідея твору. У статті проаналізовано зміст поняття ініціації як специфічного соціально-психологічного феномену та іiі різновиди. Визначено, що ситуації, у які потрапляють герої новел С. Цвейга і при цьому переживають миті духовного прозріння, $\epsilon$ межовими (пограничними). Саме в такі моменти із персонажами відбуваються «стихійні» ініціації й онтологічні перетворення. Це знаходить вираження в їхньому образі мислення, у поведінці, в їхніх часто фатальних вчинках. Доведено, що ініціація і $є$ кульмінацією новели, а відповідно, i ії поетикальною ознакою, закладеною в самій ії̈ природі. У науковій розвідці наведено приклади проходження ініціації головними героями новел «Амок», «24 години 3 життя жінки», «Пекуча таємниця». Наукова новизна. Проблема ініціації як соціально-психологічного феномену включена в саму жанрову природу новел С. Цвейга становить наукову новизну цієї статті. Практичне значення результатів дослідження полягає в можливості їхнього використання при подальшому вивченні поетикальної специфіки новелістичної спадщини С. Цвейга, а також при підготовці студентів-філологів до практичних і семінарських занять.

Ключові слова: новела, ініціація, кульмінація, сюжет, підсюжет, стихійна ініціація, поетикальна ознака, межова ситуація.

\section{INITIATION AS A POETIC FEATURE OF SHORT STORIES BY S. ZWEIG (SCIENTIFIC AND METHODICAL MATERIALS FOR STUDYING A NOVELISTIC HERITAGE OF THE WRITER IN HIGH SCHOOL)}

\section{Olena Terekhovska}

Ph. D. in Philology, Assistant Professor,

Department of World Literature and Comparative Literary Criticism, Vasyl Stefanyk Precarpathian National University (UKRAINE),

76018, Ivano-Frankivsk, 57, Shevchenko str., e-mail: olena.terekhovska@pu.if.ua 


\section{ABSTRACT}

The article deals with the poetical specifics of short stories by S. Zweig, in particular in the aspect of their structure. The aim of the article is to prove that the initiation is a poetic feature of short stories by S. Zweig, as well as to generalize and adapt the scientific and theoretical material regarding this problem for students, who study philology during their preparation for practical and seminary classes. The research method consists of extrapolation of the meaning of initiation as a specific socio-psychological phenomenon into the short stories of S. Zweig, as well as in the definition of initiation, which forms the content and essence of the climax moment in the short stories, a specific poetic feature of this genre. The results of the research. It is proved that the climax moment, embedded in the nature of short story at the level of its structure, is formed due to the interaction of two specific features of the novelistic genre - the plot and the subject. It is revealed that in the plot unfolding events from the life of the character, depicts the changes to which they led in his feelings or consciousness; in the subject - the parallel disclosure of forces, which are not understood by the hero, which, however, have become the reason for such a development of events and qualitative changes in the inner world of the character - the initiation. It is established that at the climax of moment, when the plot and subject lines are crossed, the idea of a work is born. In the article is analyzed the meaning of the concept of initiation as a specific socio-psychological phenomenon and its varieties. It is determined that the situations in which the characters of S. Zweig fall into while experiencing the moment of spiritual enlightenment are boundary. Exactly during such moments the «spontaneous» initiations and ontological transformations take place with the characters of short stories. It finds expression in their way of thinking, in behavior, in their, often fatal, deeds. It is proved that initiation is the culmination of the narrative, and, accordingly, its poetic feature, lais in its very nature. In the scientific research are examples of the initiation of main characters in short stories, such as «Amok», «Twenty-four hours in the life of a woman», «Burning secret». Scientific novelty. The problem of initiation as a socio-psychological phenomenon is included in the genre of short stories by S. Zweig and constitutes the scientific novelty of the article. The practical significance of the results of research is in the possibility of its use in further study of the poetic specificity of short stories by S. Zweig as well as in the preparation of students who study philology for practical and seminary classes. situation.

Key words: short story, initiation, climax, plot, subject, spontaneous initiation, poetic sign, boundary

Новели С. Цвейга привертають пильну увагу дослідників як в ідейно-змістовому аспекті (адже письменник порушує в них болючі вічні питання щодо складності й суперечливості людських стосунків, щодо непрогнозованості поведінки закоханої людини, щодо межі між дозволеним і недозволеним у вчинках людини в ситуації екзистенційного вибору тощо), так і в аспекті поетикальному, на рівні стилю і композиції. Зокрема, композиційна природа новел письменника характеризується наявністю сюжету і підсюжету, особлива взаємодія яких обумовлює появу кульмінаційного моменту в новелі, коли герої С. Цвейга переживають духовні онтологічні зміни, миттєві й незворотні. Вони стають якісно іншими, тобто переживають «стихійні» ініціації, що дозволяє висловити гіпотезу: проблема ініціації закладена в саму природу новел письменника і є, відповідно, їхньою поетикальною ознакою. Отже, чи можна вважати проблему ініціації поетикальною ознакою новел С. Цвейга? У цьому, власне, і полягає наукова проблема пропонованої статті.

Жанрова своєрідність новел С. Цвейга неодноразово була об’єктом наукових розвідок як вітчизняних - Ю. Косенка, В. Овсяннікова, Л. Цибенко, так і зарубіжних дослідників - Б. Сучкова, Л. Наумовича, К. Федіна. У працях акцентовано на складній структурі його новел, на функціях сюжету і підсюжету, на специфіці кульмінаційного моменту. Утім, те, що кульмінаційні моменти новел письменника $є$ актами важливих духовних перетворень героїв, що герої, переживши ці моменти, опинялись у кардинально іншій ціннісній або ж віковій системі координат, не було проаналізовано. Отже, проблема ініціації як 
соціально-психологічного феномену включена в саму жанрову природу новел С. Цвейга і становить наукову новизну цієї статті.

Мета статті - довести, що проблема ініціації є поетикальною ознакою новел С. Цвейга, а також узагальнити й адаптувати науково-теоретичний матеріал 3 цієї проблеми для студентів-філологів під час їхньої підготовки до практичних і семінарських занять.

Актуальність дослідження полягає в застосуванні міждисциплінарного підходу (літературознавство, психологія, вікова фізіологія) у вивченні питань поетикальної специфіки новелістичної спадщини С. Цвейга.

Методологія дослідження базується на використанні матеріалу дослідницького блоку як літературознавчого характеру (щодо жанрової природи новели, щодо місця новели у творчості С. Цвейга), так і сучасних дослідницьких методик у галузі психології (визначення ініціації, iї різновиди).

Видатний австрійський новеліст, есеїст, драматург, автор біографічних романів та нарисів, письменник великої ерудиції та внутрішньої культури Стефан Цвейг - одна з найдраматичніших постатей західноєвропейської літератури першої половини XX століття. Він був свідком грандіозних політичних катаклізмів сучасності, що повністю змінили хід історії і долю того покоління європейської інтелігенції, до якого він належав. «Мы, те, кому сейчас шестьдесят лет... чего мы не видели, не перестрадали, не пережили? - писав він на схилі віку в мемуарах «Вчорашній світ». - Мы перелистали от корки до корки каталог всех мыслимых катастроф... Я сам был современником обеих величайших в истории человечества... Все бледные кони Апокалипсиса проскакали через мою жизнь - революции, голод, инфляция, террор, эпидемии, эмиграция... Не было страны, куда можно было бы бежать, не было покоя, который можно было бы купить, всегда и повсюду настигала нас судьба и втягивала в свою ненасытную игру» [9, с. 77].

Це саме той випадок, коли драматизм історичного часу вносить непоборний розлад у внутрішній світ художника, і митець перестає бути здатним приборкати особисту людську драму, яка зріє в його душі i завершується фатально.

Цвейг-художник дуже гостро відчував недосконалість і несправедливість світу, у якому жив. Проте вихідним пунктом його поглядів на історію, на об'єктивні обставини буття була людина, індивід, особистість, чия воля, бажання й прагнення майже не залежали від соціального середовища, людина, індивідуальне обличчя якої визначало обличчя історичного періоду, суспільних течій і рухів. Не макрокосм (світ), а мікрокосм (людина) у світі був предметом його особистого інтересу, не історичний момент, а людина в історичному моменті, не соціально-психологічні обставини, а вибір, вчинок особистості за цих обставин. Це й зумовило певні художні особливості його творів.

Зрозуміло, улюбленим жанром письменника стала новела: «...Цвейг насамперед майстер малого жанру» [11, с. 7]. Саме цей жанр із його складною i «нервовою» природою дозволив Цвейгові правдиво показати «нервовість часу», передати ним самим пережите відчуття нестійкості життєвих основ, змалювати складність і суперечливість людських характерів. Це обумовлено жанровим 
«кутом зору» новели на життєвий матеріал. Справедливо зазначає Ю. Косенко, «новела переосмислює суспільне життя і розкриває «механіку» народження нових явищ у ньому» [2, с. 64]. Новим у новелах С. Цвейга якраз є акцент на «одиничному». Письменник переносить усі суспільні катаклізми і трагічні конфлікти на долю однієї людини, і на її прикладі, на змалюванні складностей та суперечностей iіi внутрішнього світу намагається усвідомити й показати іiі трагічну залежність від світу зовнішнього. Цвейгові новели - це художній погляд під лупою (з метою збільшити, щоб побачити хаос) на людську психіку, на поведінку людини в пограничній, межовій ситуації, у момент екзистеційного вибору, коли свідоме i підсвідоме перебувають у стані конфліктної неузгодженості. Утім, межові ситуації, у які потрапляють герої новел С. Цвейга, $\epsilon$ кульмінаційними моментами, коли персонажі переживають миті духовного прозріння, стають якісно іншими, тобто такими, що пережили певну моральну ініціацію або якісне переродження. Саме такі ситуації в житті людини цікавили С. Цвейга понад усе, і саме ці миті так званих стихійних ініціацій зображував у своїх новелах письменник. Цим також обумовлений його інтерес до жанру новели.

Кульмінаційний момент закладений у саму природу новели на рівні іiі структури. Тут необхідно згадати про дві специфічні особливості новелістичного жанру: взаємодію сюжету і підсюжету та принципи будови новелістичного моменту. «У сюжеті розгортаються події з життя героя, змальовуються зміни, до яких вони призвели у його почуттях чи свідомості. У підсюжеті - паралельне розкриття сил, неусвідомлюваних героєм, які, проте, стали причиною саме такого розвитку подій і якісних змін внутрішнього світу героя. Підсюжет має в новелі усамостійнене значення... Розгортання сюжету «просвітлює» підсюжет дедалі виразніше i, коли доходить кульмінації, підсюжет «проявляється» до кінця - миттєво і виразно» [2, с. 61]. Коли схрещуються сюжетна і підсюжетна лінії новели, розкриваються важливі суперечності дійсності, що зумовили виникнення зображуваної події чи явища. Підсюжет, відкрившись до кінця, поновому висвітлює вже відоме читачеві.

Отже, вражаючий ефект новелістичного кульмінаційного моменту пояснюється тим, що відкриття життєвих суперечностей через конкретний наслідок їхньої дії веде героя до якісного переродження - ініціації. «В кульмінаційний момент, - коли схрещуються сюжетна і підсюжетна лінії, - народжується ідея твору, яка, трансформуючись через емоції читача, призводить до переоцінки певного явища дійсності» [2, с. 62]. Із зазначеного випливає, що наявність ініціації і $є$ кульмінацією новели, що, відповідно, дає змогу вважати ії поетикальною ознакою новели, закладеною в самій іiї природі.

Ініціація (лат. initiatio - здійснення таїнства, посвята) - обряд, що знаменує перехід на новий ступінь розвитку в межах певної соціальної групи. У широкому смислі - це комплекс дій (в основному обрядових), за допомогою яких удосконалюється і формально закріплюється зміна соціального статусу людини, відбувається включення його в певне замкнуте об'єднання, набуття ним особливих знань, а також функцій і повноважень [3, с. 53]. Отже, ініціація як специфічний соціально-психологічний феномен - один із можливих 
елементів технології професійного психологічного впливу на особистість: «...ініціації... можуть виступати як психотерапевтична умова, яка дає можливість усвідомити свої можливості, свої межі й визначитися зі своїми прагненнями» [4]. Психологи розрізняють два основних типи ініціації: 1) вікові ініціації, що пов'язані з переходом людини 3 однієї категорії до іншої; 2) спеціалізовані (кастові) ініціації, що визначають входження людини в те чи інше об'єднання сакрального характеру [7, с. 125-126]. Зазначене характеризує обрядову ініціацію, тобто системний, поміркований вплив на людську особистість, з метою якісно змінити іiі: той, хто ініціюється, має пережити символічну смерть, щоб у майбутньому відродитись у новій якості [3, с. 53].

У новелах С. Цвейга герої переживають не обрядову, а так звану стихійну ініціацію. Їх ніхто свідомо не випробовує, не піддає певним впливам, ніхто над ними не експериментує, їх не приймають у таємні союзи, вони не отримують доступу до того чи іншого виду магічних сил і сакральних цінностей. Все, що 3 ними відбувається, відбувається стихійно, само собою, відбувається дуже швидко (миттєво) і з величезною силою. Вони переживають онтологічну зміну, що знаходить своє вираження в їхньому образі мислення, у їхній поведінці стосовно інших людей, у їх часто фатальних вчинках. Беручи до уваги, що кінцевою метою обряду ініціації є народження нової особистості, нової людини, можна впевнено твердити, що герої новел С. Цвейга пережили ініціацію. Кожен 3 них відчуває, що всередині нього $є$ щось, що спонукає його йти саме цим шляхом. Це «щось» існує на підсвідомому рівні і не піддається аналізу. Сфера підсвідомого - така загадкова, таємнича, непередбачувана - завжди вабила С. Цвейга. Саме вона $є$ ключем для розуміння істинних мотивів поведінки людини, але ж де той ключ і де ті двері, що тим ключем відмикаються? Це питання чи не найбільше хвилювало письменника. Тут варто згадати про зацікавлення С. Цвейга теорією підсвідомого 3. Фройда, який, як відомо, базував своє вчення про підсвідоме на сфері сексуального. Віддаючи належне теоріям віденського психіатра, С. Цвейг все ж таки дивився на людину не як на комплекс психофізіологічних процесів, а як на особистість, наділену творчими здібностями. Тому фройдівському психоаналізу він протиставляв психосинтез, прагнучи зображувати людину в цілісній сукупності її проявів і можливостей $[9$, с. 91].

Отже, сфера підсвідомого як сукупність інстинктів і прихованих бажань та намірів була в центрі уваги письменника. Причому С. Цвейг був упевнений, що найбільше підсвідоме нагадує про себе в тих самих межових, пограничних ситуаціях, коли людина перестає контролювати себе, коли розум на певний час відключається, а інстинкти і приховані бажання починають керувати нею. Фактично всі герої його новел пережили подібні межові ситуації, тимчасово перебуваючи в так званому стані «амоку», коли не розум, а щось інше кудись їх вело, приймало за них доленосні рішення, підштовхувало до фатальних вчинків. Показово, що саме пограничні ситуації стали поштовхом до акту ініціації, на певну мить розкривали дверцята до таємниць людської психіки, висвітлювали приховані емоції й почуття. Новели С. Цвейга - це скрупульозне дослідження і художнє відтворення найдрібніших швидкоплинних переживань особистості, змін іiі емоційного стану, найтонших порухів психіки. Тут варто 
згадати про ще одного вчителя С. Цвейга, особистістю і творчою манерою якого він захоплювався і навіть присвятив йому біографічне есе й поему, Ф. Достоєвського. «В открывшейся ему новой сфере искусства он искал родственные духовные ценности и обрел их в творчестве Достоевского, - зазначає дослідник Б. Сучков, - оно потрясло Цвейга и сделало его одним из самых заметных последователей русского романиста на Западе» [9, с. 84]. Поділяючи погляди Достоєвського на місце і роль страждання і смирення в духовному житті людини, а також детально дослідивши біографію Ф. Достоєвського, С. Цвейг акцентував у ній на той момент, коли, на його думку, Достоєвський «народився вдруге», тобто пережив духовну ініціацію, ставши іншим, здобувши нову онтологічну духовну сутність. Це та фатальна мить, коли Ф. Достоєвський на Семенівському плацу під гуркіт барабанів, закутаний у білий плащ смертника, пережив тяжке і страшне очікування смертної кари, усвідомлюючи: все, що пов'язує його з людьми, близькими, світом, залишилось позаду, і перед ним відкривається велика невідомість, темний, бездонний провал у небуття [9, с. 85]. Вочевидь, що і в творчій біографії улюбленого письменника С. Цвейг відшукав поворотний момент, який спричинив духовну ініціацію, переродивши і звільнивши митця. Від цього моменту Достоєвський (а разом 3 ним і його літературні герої) потрапляють в інший духовний вимір, у якісно іншу ціннісну систему координат з єдиним головним пріоритетом - Людина 3 іiі вірою у Бога.

Фактично усі новели С. Цвейга - це художня фіксація тих самих поворотних моментів в житті його героїв, коли персонажі так само переживають друге народження - ініціацію, коли на зміну одній сутності героя на очах читача приходить інша сутність, причому відбувається все миттєво, тому що керує процесом не розум, а те саме «щось», приховане в надрах позасвідомого, але в певний момент звільнене.

Для прикладу звернімось до декількох новел С. Цвейга. Новела «Амок», у якій йдеться про фатальний випадок, що трапився у медичній практиці одного лікаря. Кульмінацією цієї новели є момент, коли лікар в обмін на свої послуги (перервати небажану вагітність і зберегти таємницю), користуючись ситуацією критичної безвиході для пацієнтки та своїм «службовим» становищем, запропонував їй у вигляді розрахунку замість грошей інтимні стосунки, а вона 3 гідністю і презирством відмовила: «На мить вона остовпіла. Потім - о, я не можу, не можу сказати вам, який то був жах, - потім обличчя її наче скам'яніло, а далі... далі вона несподівано зареготала... просто в вічі мені зареготала 3 невимовною погордою... та погорда розтоптала мене... Той зневажливий регіт був подібний до вибуху - такий раптовий, такий навальний, сповнений такої велетенської нечуваної сили, що я... так, я... ладен був кинутись на землю й цілувати іï ноги» [11, с. 211]. Вочевидь, що лікарю стало соромно. Він вмить зрозумів: сталося щось непоправне, він допустив фатальну помилку, яку треба негайно виправити за будь-яку ціну, бо в інакшому випадку його життя втратить сенс: «...Враз вона обернулась і швидко пішла до дверей. Я мимохіть кинувся за нею... просити пробачення, благати іiі.. <..> вона ще раз обернулась і сказала... ні, наказала: - не смійте йти за мною або вистежувати 
мене... А то пожалкуєте. I тільки двері грюкнули за нею. <..> Грюкнули двері... проте я стояв непорушно на місці... Я був ніби загіпнотизований іiі наказом...» [11, с. 212]. Лікар зізнається, що перебував тоді певний час у стані своєрідного «амоку»: «Амок?... Це щось більше за сп’яніння... Це сказ, подібний до собачого... напад кровожерної, безглуздої мономанії...» [11, с. 214]. Уся його подальша поведінка - це намагання реабілітуватись, попросити пробачення, знайти будь-яку можливість допомогти, врятувати ситуацію. «Не минуло й години від тієї миті, як ця жінка ввійшла до моєї кімнати, а я встиг уже через неї розбити вщент своє життя і мчав, гнаний амоком, у порожнечу... $<\ldots>$ моя воля була остаточно зламана, я тільки хотів допомогти їй, зробити послугу... я пішов би на вбивство, на злочин, аби тільки їй допомогти...» [11, с. 217]. Пережите лікарем - не що інше, як приклад моральної ініціації, коли людина під впливом певних життєвих обставин вмить прозріває, усвідомлюючи свою гріховність, свою ницість, каючись, і все ж таки, акумулюючи весь свій «новий» моральний ресурс, намагається запобігти неминучій трагедії. Уникнути трагедії не вдалося: пацієнтка померла. Утім, на доказ своїх щирих намірів щодо неї, на доказ своєї людської і професійної порядності він ціною власного життя рятує її жіночу честь і гідність перед чоловіком, кидаючись 3 борту пароплава на закриту труну з їі тілом і забираючи у морську безодню усі речові докази гріха. Для нього це був останній спосіб прислужитися їй, виконати iі передсмертне прохання: ліквідувати наслідки, щоб зберегти таємницю.

У новелі «24 години 3 життя жінки» ініціацію переживає доросла сорокадворічна жінка, удовиця, намагаючись врятувати від ігрової залежності зовсім юного молодика, чиє життя в небезпеці через шалені борги і неймовірну одержимість грою в казино. Героїня мала спокійне, забезпечене життя у любові і злагоді з чоловіком, не знаючи горя і смутку. Після смерті коханого чоловіка їi життя втратило сенс: «Відтоді моє життя втратило сенс. <..> У мене не було ані надій, ані сподівань» [12, с. 13]. Щоб розвіяти смуток і не завдавати зайвого клопоту дорослим синам, що вже не потребували іiі особливої опіки, вона вирішила провести найближчі роки у мандрах, опинившись таким чином у Монте-Карло, де у казино і познайомилась 3 хлопчиною. Вона була вражена вишуканою красою його рук, що значно вирізнялись 3-поміж інших: «Це були руки рідкісної вишуканої краси, і разом 3 тим м'язисті, незвично довгі, незвично вузькі, дуже білі - 3 блідими кінчиками нігтів i вишуканими перламутровими лунками. Я дивилася на ці руки увесь вечір, вони вражали мене своєю неповторністю...» [12, с. 16]. За нервовим хрустом його пальців, а також безумно-пристрасним виразом обличчя юнака, вона зрозуміла, що він хворий грою, гра його згубить, він вже гине, і йому негайно потрібна допомога. Побачивши його на лавці під зливою, абсолютно спустошеного, відчуженого, мокрого і холодного, вона була шокована: «...я нерішуче тупцювала на місці, вражена й загіпнотизована видовищем повного знищення людини» [12, с. 23], але не змогла покинути його напризволяще. Жінка миттєво зрозуміла: якщо юнакові не допомогти, він щось із собою зробить, і вона, не замислюючись про наслідки, простягає йому руку допомоги: «Я не могла цього витримати; я 
кинулась до нього крізь холодну зливу й струснула його: «Ходімо!»< ..> я й сама не знала, куди його відвести, тільки б геть звідси, від цієї холодної зливи, від цієї безглуздої самогубної пози повного відчаю!» [12, с. 24]. I потім, коли вони опинились у маленькому готелі, і вона віддалась йому, все одно вона була твердо переконана, що рятувала хлопця: «Тієї ночі я боролася з людиною за їі життя; повторюю - йшлося про життя і смерть. Надто ясно я відчувала, що ця чужа, вже майже приречена людина жадібно і пристрасно хапається за мене, як потопельник хапається за соломинку» [12, с. 29]. Рятівний материнський інстинкт пробудив у ній спляче жіноче начало, пробудив їі до життя, воскресив iii: «... він був урятований, і врятувала його я. I я дивилася материнським поглядом (інакше не можу назвати) на сплячого, якого я повернула до життя, немовби знову народивши, iз ще більшими муками, аніж власних дітей!» [12, с. 31]. Вочевидь, жінка пережила ініціацію. Із розпещеної, зацикленої на своєму горі і байдужої до навкілля пані вона перетворилась на жертовну рятувальницю, яка в ім'я спасіння людини, що гине, порушує норми моралі, виказуючи тим самим прагнення до добра, властиве людській природі. I хоча врешті-решт врятувати хлопця не вдалося, жінка зробила те, що змогла, що вважала за необхідне - проявила небайдужість, милосердя і людяність.

У новелі «Пекуча таємниця» ініціацію переживають одразу два персонажі (причому кожен свою) - хворобливий дванадцятирічний хлопчик на ім'я Едгар, що дорослішає, і його мати - ще доволі молода красива жінка, яка усвідомлює плинність часу, скороминучість своєї краси і молодості. Обом бракує любові й уваги: хлопчикові - уваги з боку батьків, друзів, а його мама відчуває дефіцит чоловічої ніжності й турботи. Пригода в санаторії (флірт матері з бароном i спроби хлопчика захистити свою матір) повністю перевертає світ обох. Едгар змінюється на очах: із сором'язливого, фізично не дуже розвиненого, нервового хлопчика він перетворюється на чоловіка, рішучого, сміливого, відчайдушного. У ньому з'являються чоловічі хижі власницькі інстинкти, він готовий чинити опір, боротися і захищати. Едгар переживає перш за все вікову ініціацію. У нього формуються справжні дорослі чоловічі звички - бути господарем на своїй території, вміти захистити й відстояти те, що належить йому. Істинних намірів барона стосовно своєї матері він зрозуміти не міг, але хлопчик інстинктивно відчував, що коїться щось неправильне, що його мати в небезпеці: «Я не знаю, що він пообіцяв тобі і чому він такий милий з тобою, але і від тебе він щось хоче. <..> Це поганий чоловік. Він бреше. Ти тільки подивися, як нещиро він усміхається. Ти повинна стерегтися його. Той, хто збреше раз, зробить це i вдруге. Він поганий чоловік, йому не можна довіряти» [11, с. 82-83]. Дорослішаючи, хлопчик почав усвідомлювати складність і суперечливість дорослого світу, неодмінними атрибутами якого $є$ фальш, лицемірство, корисливість. Цей новий для нього світ ховає у собі багато таємниць, похмурих i водночас пекучих таємниць, пов'язаних із болем, інтригами, брехнею. Його вчорашній дитячий світ цих понять не знав, тому так важко йому далася розлука 3 дитинством: «Це був останній плач його втраченого дитинства, прощальний вибух сліз, він востанне по-жіночому віддався розкоші плачу. Протягом цієї години самовідданої люті він виплакав із себе все - довіру, 
любов, побожність, повагу - усе своє дитинство» [11, с. 80]. Отже, ініціація Едгара - це складний болісний перехід хлопчика у світ дорослих, усвідомлення неоднозначності цього світу, усвідомлення відсутності двомірності (добро-зло, правда-брехня) оцінок у ньому. Цей світ відкрив перед ним двері перших глибоких переживань і тривог.

Завдяки хлопчикові переживає свою ініціацію і його мати. Коли Едгар, образившись на неї, зник, усе змінилось в ії свідомості. Відбулася стихійна переоцінка цінностей, головне і важливе знову стало на своє пріоритетне місце. Самолюбні егоїстичні бажання вмить щезли, поступившись любові до сина та сімейним обов'язкам. Дуже важливою з погляду усвідомлення змін у ній $\epsilon$ фінальна сцена, коли вона заходить до хлопчика в кімнату i, каючись, пестить та голубить його: «Він відчув на щоці чийсь подих, теплий і приємний, він знав, що це мати схилилася над ним, цілує і гладить його по голові. Він насолоджувався іiі поцілунками і іiі сльозами, поцілував іiі у відповідь і зрозумів, що це примирення і подяка за його мовчання» [11, с. 110]. Тепер між ними знову мир, злагода, але вони вже інші. Таємниця, яку зберіг Едгар, їх змінила: хлопчик став дорослим, а мати зрозуміла, що нікого і нічого важливішого за сина в іiі житті не було і бути не може: «Аж через багато років він збагнув, що ці мовчазні сльози були ще й особливою обіцянкою жінки на порозі старіння, обіцянкою, що відтепер вона належатиме тільки йому, тільки своїй дитині, що вона відмовляється від пригод, прощається з надією на палку пристрасть. Він не знав, що і вона була вдячна йому за порятунок від небезпечної пригоди i цими обіймами передала йому солодкаво-гірку ношу любові, ніби спадок для майбутнього життя. Усе це хлопець тоді ще не розумів, але відчував, як приємно, коли тебе так люблять, і що ця любов якось пов'язує його $з$ тією найбільшою у світі таємницею» [11, с. 110].

Отже, кульмінаційний момент, закладений у саму природу новели на рівні iï структури, і $є$ моментом ініціації іiі героїв, переживши яку, вони усвідомлюють себе якісно іншими. Ініціація є сильним каталізатором для духовного переродження, оскільки спричиняє глибоку особистісну перебудову. Схрещення сюжетної і підсюжетної ліній у новелі розкриває важливі суперечності дійсності, що зумовили виникнення ситуації чи обставин, у які потрапляють герої і згодом переживають стихійні ініціації. Механізм, покладений в основу переживань людини, що проходить ініціацію, можна порівняти зі станом символічної смерті: вмерти, щоб потім відродитись у новій якості. Саме цей стан і переживають герої новел С. Цвейга. Наявність ініціації $є$ кульмінацією новели, i, відповідно, іiї поетикальною ознакою, закладеною в саму іiі структуру.

\section{ЛІТЕРАТУРА}

1. Федин К. А. Драма Стефана Цвейга. Писатель. Искусство. Время. Москва : Сов. писатель, 1980. С. 277-281.

2. Косенко Ю. Про жанрову свосрідність новели. Радянське літературознавство. 1973. № 3. С. 61-66. 
3. Матеюк О. А. Ініціації як форма психологічного впливу на особистість. Вісник Київського національного університету імені Тараса Шевченка. Військово-спеціальні науки. Київ, 2009. Вип. 23. С. 53-54.

4. Мухина В. С. Инициации подростков во временных объединениях как условие личностного роста. Развитие личности. 2000. № 1. С. 79-107.

5. Наумович Л. Природа в новеллах Стефана Цвейга. Вопросы национальной специфики произведений зарубежной литературы XIX-XX веков : межвуз. сборник науч. трудов / Отв. ред. Шейнкер В. Н. Иваново : Изд-во Иванов. ун-та, 1979. С. 145-157.

6. Овсянніков В. В. Використання антитези в новелах С. Цвейга. Іноземна філологія: міжвід. респ. зб. Львів, 1972. Вип. 29. С. 27-36.

7. Платов А. В. Традиционные посвящения : бессмертие и свобода. Muфbl и магия индоевропейцев. Москва, 2002. Вып. 10. С. 124-137.

8. Рубинштейн С. Л. Проблемы общей психологии / отв. ред. Е. В. Шорохова. Москва : Педагогика, 1973. 424 с.

9. Сучков Б. Лики времени. Статьи о писателях и литературном процессе. Москва : Худож. лит., 1976. Т. І. 416 с.

10. Цибенко Л. Дискурс австрійської літератури в сучасній германістиці. Вікно в світ. 1998. № 2. С. 7-11.

11. Цвейг С. Лист незнайомої : новели / пер. 3 нім. ; передм. Д. В. Затонського. Харків : Фоліо, 2010. $411 \mathrm{c}$.

12. Zweig S. Verwirrung der Gefühle. Drei Novellen. (Vierundzwanzig Stunden aus dem Leben einer Frau. Untergang eines Herzens. Verwirrung der Gefühle). Leipzig : Insel-Verlag, 1927. URL: http://originalbook.ru/24-stunden-aus-dem-leben-einer-frau-stefan-zweig-deutsch (дата звернення: 12.03.2019).

\section{REFERENCES}

1. Fedyn, K.A. (1980), "Drama by Stefan Zweig", Writer. Art. Time ["Drama Stefana Tsveiga", Pisatel. Iskusstvo. Vremya], Sov. pisatel, Moscow, pp. 277-281. (in Russian).

2. Kosenko, J. (1973), "About the genre's peculiarity of the novella" ["Pro zhanrovu svoiieridnist novely"], Radianske literaturoznavstvo, No. 3, pp. 61-66. (in Ukrainian).

3. Matejuk, O.A. (2009), "Initiation as a form of psychological impact on personality" ["Initsiatsii yak forma psykholohichnoho vplyvu na osobystist"], Visnyk Kyivskoho natsionalnoho universutetu imeni Tarasa Shevchenka. Viiskovo-spetsialni nauky. Issue 23, pp. 53-54. (in Ukrainian).

4. Mychyna, V.S. (2000), "Initiation of adolescents in temporary associations as a condition for personal growth" ["Initsiatsii podrostkov vo vremennykh obedineniyakh kak uslovie lichnostnoho rosta"], Razvitie lichnosti, No. 1, pp. 79-107. (in Russian).

5. Naumovich, L. (1979), "Nature in the novels by Stefan Zweig", Questions of national specificity of works of foreign literature of the nineteenth and twentieth centuries ["Priroda $\mathrm{V}$ novellakh Stefana Tsveiga", Voprosy natsionalnoy spetsyfiki zarubezhnoy literatury XIX-XX vekov], Ivanovo, pp. 145-157. (in Russian).

6. Ovsyannikov. V.V. (1972), "The using of antithesis in S. Zweig's short stories" ["Vykorystannia antytezy v novelakh S. Tsveiga"], Inozemna filologia. Mizhvid. resp. zbirnyk, Vyp. 29, pp. 27-36. (in Ukrainian).

7. Platov, A.B. (2002), "Traditional initiations: immortality and freedom" ["Traditsionnye posvyascheniya: bessmertie i svoboda"], Mify i magiya indoyevropeytsev, Issue 10, pp. 124-137. (in Russian).

8. Rubinshteyn, S.L. (1973), Problems of general psychology [Problemy obschey psykhologii], Pedagogika, Moscow, 424 p. (in Russian).

9. Suchkov, B. (1976), Faces of time. Articles about the writers and the literary process. Vol. 1 [Liki vremeni. Stati o pisatelyakh i literatyrnom processe. T. 1], Khudozh. Lit., Moscow, 416 p. (in Russian). 
10. Tsybenko, L. (1998), "The discourse of Austrian literature in contemporary Germanism" ["Dyskurs avstraliiskoi literatury v suchasnii germanistytsi"], Vikno v svit, No. 2, pp. 7-11. (in Ukrainian).

11. Zweig, S. (2010), A letter from unfamiliar: short stories, trans. from Germany [Lyst neznaiomoi: novely, per. z nim.], Folio, Kharkiv: 411 p. (in Ukrainian).

12. Zweig, S. (1927), Confusion of emotions. Three short stories. (Twenty-four hours from the life of a woman, sinking of a heart, confusion of feelings).[Verwirrung der Gefühle. Drei Novellen. (Vierundzwanzig Stunden aus dem Leben einer Frau. Untergang eines Herzens. Verwirrung der Gefühle)], Insel-Verlag, Leipzig, available at: http://originalbook.ru/24-stunden-aus-dem-lebeneiner-frau-stefan-zweig-deutsch (in German).

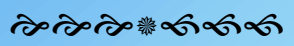

